\title{
PENGARUH HARGA DAN KARAKTERISTIK KONSUMEN TERHADAP PERMINTAAN TEMPE DI KOTA MATARAM
}

\author{
Dudi Septiadi \\ Program Studi Agribisnis, Fakultas Pertanian, Universitas Mataram \\ Email : dudi@unram.ac.id \\ Andi Iva Mundiyah \\ Program Studi Agribisnis, Fakultas Pertanian, Universitas Mataram \\ Email : andiva@unram.ac.id \\ Ni Made Wirastika Sari \\ Program Studi Agribisnis, Fakultas Pertanian, Universitas Mataram \\ Email : wirastikasari@unram.ac.id
}

\begin{abstract}
Abstrak
Kedelai merupakan jenis tanaman pangan strategis yang memiliki kandungan protein dan gizi yang baik. Tempe merupakan olahan kedelai yang digemari semua kelas sosial dan ekonomi. Tujuan Penelitian ini adalah untuk; (1) menganalisis karakteristik responden yang mengkonsumsi tempe di Kota Mataram; (2) menganalisis pengaruh harga dan karakteristik konsumen terhadap permintaan tempe di Kota Mataram. Metode analisis yang digunakan pada penelitian ini adalah analisis regresi linier berganda dengan menggunakan alat analisis SPSS 17.0. Penelitian dilakukan di Kota Mataram dengan sampel konsumen sebanyak 30 responden. Hasil penelitian menunjukkan karakteristik konsumen yang mengkonsumsi tempe di Kota Mataram berbeda-beda berdasarkan posisi dalam keluarga, jenis kelamin, umur, tingkat pendidikan, jenis pekerjaan, dan jumlah anggota keluarga. Hasil analisis menunjukkan variabel harga tempe dan variabel pendapatan keluarga dinyatakan memiliki pengaruh terhadap permintaan tempe. Secara serentak variabel independen dalam model memiliki pengaruh yang nyata terhadap permintaan tempe. Hasil analisis koefisien determinasi menunjukkan bahwa model yang dibangun dalam penelitian ini mampu menjelaskan variasi perubahan permintaan tempe sebesar 99,7 persen, sedangkan sisanya 0,7 persen dijelaskan oleh variabel lain diluar model.
\end{abstract}

Kata kunci: Harga, Kedelai, Permintaan, Regresi Linier Berganda, Tempe.

\begin{abstract}
Soybean is a type of strategic food plant that contains good protein and nutrition. Tempe is a soybean product that is popular with all social and economic classes. The purpose of this research is; (1) to analyze the characteristics of the respondents who consumed tempe in Mataram City; (2) to analyze the effect of price and consumer characteristics on demand for tempe in Mataram City. The analytical method used in this study is multiple linear regression analysis using the SPSS 17.0 analysis tool. The research was conducted in the city of Mataram with a sample of 30 consumers. The results of this study showed that the characteristics of consumers who consume tempe in Mataram City vary based on family position, gender, age, education level, type of work, and number of family members. The results of the analysis showed that the tempe price variable and the family income variable are stated to have an influence on the demand for tempe. Simultaneously the independent variable in the model has a significant effect on the demand for tempe. The results of the coefficient of determination analysis showed that the model built in this study is able to explain the variation of changes in tempe demand by 99.7 percent, while the remaining 0.7 percent is explained by other variables outside the model.
\end{abstract}

Keywords: Demand, Multiple Linear Regression, Price, Soybean, Tempe.

\section{PENDAHULUAN}

Sektor pertanian memiliki peran strategis dan dominan dalam suatu perekonomian Negara. Hal ini tidak lepas dari karakteristik wilayah di Indonesia merupakan wilayah agraris dan sebagian besar masyarakat bekerja di sektor pertanian (Nursan \& Septiadi, 2020). Pentingnya sektor pertanian tercermin dari kontribusinya terhadap nilai Produk Domestik Bruto dari tahun ke tahun di Indonesia (Septiadi et al., 2020). Sub sektor pertanian tanaman pangan merupakan sub sektor paling vital di sektor pertanian 
(Septiadi et al., 2019). Sub sektor pertanian tanaman pangan dianggap penting dikarenakan menjadi tumpuan dalam memenuhi kebutuhan pokok (Suparyana et al., 2020). Kedelai merupakan salah satu komoditas tanaman pangan utama setelah tanaman padi dan jagung. Posisinya sebagai salah satu jenis tanaman pangan sangat dibutuhkan masyarakat. Jumlah penduduk Indonesia yang sangat besar berdampak pada permintaan komoditas kedelai dan turunan produknya seperti tempe, tahu, tauco, kecap dan susu sangat tinggi. Selain konsumsi rumah tangga, komoditas kedelai sudah dibutuhkan sektor industri sebagai bahan baku produksi, hingga sebagai pakan ternak.

Berdasarkan data secara agregasi nasional menurut (Triastono, Kurniyati, \& Jatuningtyas, 2020) dibutuhkan kedelai sebanyak 2,7 juta ton setiap tahun untuk memenuhi konsumsi dalam negeri. Jika dilihat dari sisi produk turunannya seperti tempe, konsumsi tempe rata-rata tiap orang per tahun di Indonesia saat ini diperkirakan sekitar 6,45 kg (Astawan, 2003). Berdasarkan sisi penawaran, jumlah pasokan kedelai untuk kebutuhan domestik belum memadai. Kebijakan impor dilakukan pemerintah untuk memenuhi kebutuhan domestik akan komoditas kedelai. Realitas kebijakan impor merupakan masalah klasik yang diahadapi semua jenis tanaman pangan termasuk kedelai (Septiadi, Harianto \& Suharno, 2016). Peluang ini menjadi peluang yang menjanjikan untuk usahatani budidaya kedelai untuk memenuhi kebutuhan dalam negeri (Septiadi et al., 2020). Hal ini dikarenakan kedelai memiliki produk turunan yang beragam, salah satunya yang banyak disukai masyarakat adalah tempe.

Tempe merupakan makanan asli dari Indonesia yang telah dikonsumsi selama puluhan abad. Secara historis di masa lampau, tempe dianggap sebagai makanan kelas bawah (inferior), akan tetapi hari ini tempe merupakan makanan primadona bagi semua kalangan. Hal ini tidak mengherankan karena kandungan protein kedelai cukup tinggi, dan nilai gizinya mirip dengan protein hewani yang memiliki nilai biologic tinggi (Winarsi \& Purwanto 2010). Berdasarkan pada kelebihan komoditas kedelai tersebut sebagai bahan dasar olahan tempe, hal ini menjadikan tempe menjadi makanan khas Indonesia yang masih bertahan hingga saat ini.

Provinsi Nusa Tenggara Barat (NTB) merupakan salah satu daerah penghasil kedelai. Sehingga banyak Agroindustri yang menjalankan usaha pengolahan kedelai menjadi tempe. Agroindustri di Provinsi Nusa Tenggara Barat sebagian besar berupa usaha kecil atau usaha rumah tangga. Berdasarkan data Dinas Perindustrian Provinsi NTB tercatat jumlah industri kecil menengah di Nusa Tenggara Barat tahun 2015 sebanyak 2.220 sentra yang terdiri dari 74.894 unit usaha. Dari data tersebut bila dilihat untuk daerah Kota Mataram, maka jumlah industri atau agroindustri yang terdapat di wilayah tersebut sebanyak 416 sentra usaha yang terdiri dari berbagai cabang diantaranya Pandang, Sandang, Kimia dan Bahan Bangunan, 4 Logam dan Elektronika serta Cabang Kerajinan. Dari berbagai cabang tersebut, agroindustri pangan merupakan cabang industri terbanyak yang ada di Kota Mataram yaitu sebanyak 226 sentra usaha. Jika di breakdown lebih lanjut, dari 226 sentra industri usaha tersebut, terdapat 2.576 unit usaha agroindustri tempe yang ada di Kota Mataram dengan skala UMKM (Ashari, 2018). Agroindustri tempe yang dijalankan masyarakat Kota Mataram masih sangat tradisional mulai dari tahap pengolahannya sampai tahap pemasarannya. Namun, dalam proses produksinya agroindustri tempe di Kota Mataram masih bergantung dari penggunaan bahan baku kedelai impor. Hal ini disebabkan karena ketersediaan, mutu dan harga kedelai lokal masih di bawah kedelai impor. 
Diferensiasi produk merupakan kebijakan strategis yang tepat untuk meningkatkan perekonomian di daerah. Adanya nilai tambah dari proses diferensiasi produk berupa olahan makanan yang berbahan dasar komoditas pertanian mendorong meningkatnya output sektor pertanian. Tempe merupakan salah satu produk olahan makanan berbahan dasar kedelai yang banyak digemari masyarakat di berbagai kelas sosial. Secara kandungan gizi, tempe juga cukup baik bagi kesehatan. Tingginya tingkat konsumsi tempe, baik ditingkat nasional maupun regional menunjukkan produk tempe digemari oleh berbagai kalangan sosial. Menurut hasil penelitian Ulfa (2011), menunjukkan bahwa faktor faktor yang mempengaruhi permintaan tempe adalah harga tempe, harga tahu, harga telur, harga daging ayam, harga ikan, jumlah anggota keluarga dan pendapatan keluarga. Faktor-faktor tersebut menarik untuk diteliti lebih lanjut. Hal ini menjadi dorongan bagi penulis untuk mengkaji lebih dalam tentang analisis faktor-faktor yang mempengaruhi permintaan tempe di Kota Mataram. Berdasarkan uraian tersebut, penelitian ini bertujuan untuk : (1) menganalisis karakteristik responden yang mengkonsumsi tempe di Kota Mataram; (2) menganalisis pengaruh harga dan karakteristik konsumen terhadap permintaan tempe di Kota Mataram.

\section{METODE}

Penelitian ini dilaksanakan di Kota Mataram Provinsi Nusa Tenggara Barat. Pengumpulan data untuk penelitian ini dilaksanakan mulai bulan Oktober 2019 sampai November 2019. Unit analisis yang digunakan dalam penelitian ini adalah masyarakat yang mengkonsumsi tempe di Kota Mataram. Metode pengambilan sampel yang digunakan dalam penelitian ini yaitu purposive random sampling atau pengambilan sampel secara sengaja berdasarkan tujuan kebutuhan dalam masalah penelitian di Kota Mataram. Responden yang dijadikan sampel pada penelitian ini sebanyak 30 responden. Data yang dikumpulkan kemudian dianalisis dengan analisis regresi linier berganda dengan menggunakan aplikasi Statistical Product and Service Solution (SPSS) 17.0.

Konsep variabel yang digunakan pada penelitian ini dijabarkan dalam bentuk variabel dependen dan independen. Variabel dependen dalam penelitian ini adalah jumlah permintaan tempe. Sedangkan variabel independen meliputi faktor harga dan faktor karakteristik responden. Faktor harga diantaranya adalah variabel harga tempe $\left(\mathrm{x}_{1}\right)$, variabel harga tahu $\left(\mathrm{x}_{2}\right)$, dan variabel harga telur $\left(\mathrm{x}_{3}\right)$. Sedangkan Faktor karakteristik responden diantaranya adalah variabel jumlah anggota keluarga $\left(\mathrm{x}_{4}\right)$, dan variabel pendapatan anggota keluarga $\left(\mathrm{x}_{5}\right)$.

Model persamaan regresi linier berganda untuk permintaan tempe adalah sebagai berikut:

$$
Y=a+b_{1} x_{1}+b_{2} x_{2}+b_{3} x_{3}+b_{4} x_{4}+b_{5} x_{5}+\varepsilon
$$

Keterangan :

$\mathrm{Y}=$ Permintaan tempe $(\mathrm{kg} / \mathrm{bulan})$

a $=$ Konstanta

$\mathrm{b}=$ Koefisien regresi

$\mathrm{x}_{1}=$ Harga tempe $(\mathrm{Rp} / \mathrm{kg})$

$\mathrm{x}_{2}=$ Harga tahu $(\mathrm{Rp} / \mathrm{kg})$

$\mathrm{x}_{3}=$ Harga telur $(\mathrm{Rp} / \mathrm{kg})$

$\mathrm{x}_{4}=$ Jumlah anggota keluarga (orang) 
$\mathrm{X}_{5}=$ Pendapatan keluarga $(\mathrm{Rp} / \mathrm{bulan})$

$\varepsilon \quad=$ galat atau residu

Untuk memvalidasi bentuk persamaan regresi berganda di atas perlu dilakukan uji statistik, yaitu Uji tStatistik, Uji F-Statistik, uji koefisien determinasi (R square), dan uji asumsi klasik.

\section{HASIL DAN PEMBAHASAN}

\section{Karakteristik Responden}

Peneliti menggali informasi perihal karakteristik umum terkait dengan profil dan kondisi objektif responden di lapangan. Karakteristik responden merupakan bagian yang terpenting dari suatu penelitian untuk mengetahui keadaan responden. Responden dalam penelitian ini adalah masyarakat yang bertempat tinggal di daerah sekitar kota mataram. Penjelasan lebih lanjut adalah sebagai berikut

\section{Jenis Kelamin Responden}

Karakteristik ini ingin melihat seberapa banyak persentase konsumen tempe berdasarkan jenis kelamin. Berdasarkan Tabel 1. menunjukkan bahwa responden dalam penelitian ini secara keseluruhan terbagi secara merata, yaitu responden berjenis kelamin perempuan sebanyak 50 persen dan responden berjenis kelamin laki-laki sebanyak 50 persen. Hasil ini menunjukkan konsumen yang dijadikan responden tersebar secara berimbang.

\section{Posisi Dalam Keluarga}

Karakteristik yang berkaitan dengan posisi seseorang di dalam keluarga menunjukkan peran orang tersebut dalam struktur di dalam keluarga. Dalam satu keluarga biasanya terdiri dari kepala keluarga, istri/ibu dan anak. Berdasarkan Tabel 1 menunjukkan bahwa posisi dari responden dalam keluarga adalah istri yang umumnya ibu rumah tangga dengan jumlah responden sebanyak 20 orang (66,67 persen). Dan sisanya 10 orang (33,33 persen) sebagai kepala keluarga.

Tabel 1. Jenis Kelamin dan Posisi dalam Keluarga Responden

\begin{tabular}{llcc}
\hline No & \multicolumn{1}{c}{ Uraian } & Jumlah & Persentase (\%) \\
\hline 1 & Jenis Kelamin Responden & 15 & 50 \\
& a. Laki-laki & 15 & 50 \\
& b. Perempuan & 30 & 100 \\
\hline \multirow{2}{*}{ Jumlah } & Posisi dalam Keluarga & & \\
& a. Kepala Keluarga & 10 & 33,33 \\
& b. Istri/Ibu & 20 & 66,67 \\
& c. Anak & 0 & 0 \\
& d. Lainnya & 0 & 0 \\
\hline
\end{tabular}

Sumber: Data Primer, 2020 (diolah).

\section{Jenis Pekerjaan}

Bekerja merupakan salah satu kegiatan yang dilakukan secara teratur dalam jangka waktu tertentu dengan tujuan mendapatkan penghasilan. Secara umum jenis pekerjaan akan membedakan tingkat 
pendapatan dan dapat menggambarkan kondisi ekonomi sebuah keluarga.. Dalam penelitian ini jenis pekerjaan yang akan dijabarkan adalah pekerjaan dari responden tersebut pada saat mengisi kuesioner. Berdasarkan Tabel 2, menunjukkan bahwa sebanyak 1 orang (3,33 persen) bekerja sebagai pegawai swasta, 5 orang $(16,67)$ sebagai pedagang, 2 orang $(6,67$ persen $)$ sebagai PNS, 2 orang $(6,67$ persen) sebagai petani, 1 orang (3,33 persen) sebagai dokter dan sisanya yang paling mendominasi sebanyak 19 orang (63,33 persen) sebagai Ibu Rumah Tangga. Sebagian besar responden merupakan Ibu rumah tangga, posisinya sebagai anggota keluarga yang menerima penghasilan dari suami sebagai kepala keluarga. Hasil ini sejalan dengan penelitian (Septiadi et al., 2020) yang menyatakan bahwa penghasilan ibu rumah tangga tersebut digunakan untuk membeli kebutuhan pangan keluarga. Kebutuhan tersebut termasuk diantaranya adalah kebutuhan untuk tempe sebagai makanan di rumah

\section{Tingkat Pendidikan}

Tingkat pendidikan seseorang sangat menentukan seberapa besar pengetahuan yang dimilikinya. Pendidikan juga sangat diperlukan untuk memasuki dunia kerja. Tingginya pendidikan seseorang juga akan menentukan kesempatan memperoleh jenis pekerjaan yang layak. Tingkat pendidikan di masyarakat Kota Mataram sangat bervariasi. Berdasarkan tabel 3.2. menunjukkan bahwa sebanyak 3 orang (10 persen) tamat SD, 3 orang (10 persen) tamat SMP, 16 orang (53,33 persen ) tamat SMA, dan sisanya 8 orang (26,67 persen ) tamat perguruan tinggi.

Tabel 2. Jenis Pekerjaan dan Tingkat Pendidikan Responden

\begin{tabular}{llcc}
\hline No & Uraian & Jumlah & Persentase $(\%)$ \\
\hline 1 & Jenis Pekerjaan & 1 & 3,33 \\
& a. Pegawai Swasta & 5 & 16,67 \\
& b. Pedagang & 2 & 6,67 \\
& c. PNS & 2 & 6,67 \\
& d. Petani & 19 & 63,33 \\
e. Ibu Rumah Tangga & 1 & 3,33 \\
f. Dokter & 30 & 100 \\
\hline Jumlah & Tingkat Pendidikan & & 0 \\
a. Tidak Sekolah & 0 & 10 \\
b. SD & 3 & 10 \\
c. SMP & 3 & 53,33 \\
d. SMA & 16 & 26,67 \\
e. Perguruan Tinggi & 8 & 100 \\
\hline Jumlah & 30 &
\end{tabular}

Sumber: Data Primer, 2020 (diolah).

\section{Kisaran Umur Responden}

Kisaran umur responden yang mengkonsumsi tempe di Kota Mataram berbeda-beda. Berdasarkan tabel 3.3. menunjukkan bahwa sebanyak 29 orang (96,67 persen ) berumur 15 sampai 64 tahun dan sisanya 1 orang $(3,33$ persen $)$ berumur $>64$ tahun. 


\section{Jumlah Anggota Keluarga}

Jumlah anggota keluarga juga dapat berpengaruh pada seberapa banyak pembelian tempe di Kota Mataram. Berdasarkan tabel 3.3. menunjukkan bahwa sebanyak 7 orang (23,33 persen) memiliki 1 sampai 2 jumlah anggota keluarga, 14 orang (46,67 persen ) memiliki 3 sampai 4 anggota keluarga, dan sisanya 9 orang (30 persen) memiliki > 4 jumlah anggota keluarga.

Tabel 3. Kisaran Umur dan Jumlah Anggota Keluarga

\begin{tabular}{|c|c|c|c|}
\hline No & Uraian & Jumlah & Persentase $(\%)$ \\
\hline \multirow[t]{5}{*}{1} & Kisaran Umur Responden & & \\
\hline & a. $<15$ Tahun & 0 & 0 \\
\hline & b. 15-64 Tahun & 29 & 96,67 \\
\hline & c. $>64$ Tahun & 1 & 3,33 \\
\hline & Jumlah & 30 & 100 \\
\hline \multirow[t]{5}{*}{2} & Jumlah Anggota Keluarga & & \\
\hline & a. $1-2$ & 7 & 23,33 \\
\hline & b. $3-4$ & 14 & 46,67 \\
\hline & c. $>4$ & 9 & 30 \\
\hline & Jumlah & 30 & 100 \\
\hline
\end{tabular}

Sumber: Data Primer, 2020 (diolah).

\section{Faktor-faktor yang Mempengaruhi Permintaan Tempe}

Fungsi permintaan tempe di Kota Mataram menggunakan persamaan regresi linier berganda bentuk logaritma natural dalam pengolahannya. Untuk pembahasan permintaan tempe di Kota Mataram dapat dilihat pada tabel berikut ini.

Tabel 4. Hasil Estimasi Permintaan Tempe di Kota Mataram

\begin{tabular}{lccc}
\hline Variabel & Koefisien & t-Hitung & Signifikan \\
\hline Konstanta & $-4,044$ & $-54,973$ &, 000 \\
Harga Tempe & 1,011 & 56,204 &, 000 \\
Harga Tahu &, 007 &, 752 &, 459 \\
Harga Telur &,- 011 &,- 947 &, 353 \\
Jumlah Anggota Keluarga &, 006 & 335 &, 740 \\
Pendapatan &,- 017 & $-2,248$ &, 034 \\
\hline R square & 0,997 & & \\
F hitung & 1629,23 & & \\
Signifikan F & 0,000 & & \\
\hline
\end{tabular}

Sumber: Data Primer, 2020 (diolah).

Berdasarkan hasil pada tabel di atas dapat dibuat persamaan regresi linier berganda untuk faktorfaktor yang mempengaruhi permintaan tempe di Kota Mataram. Sesuai dengan model persamaan yang dijabarkan pada metodologi penelitian, maka persamaan regresinya adalah sebagai berikut;

$$
\mathrm{Y}=-4,044+1,011 \mathrm{x}_{1}+0,007 \mathrm{x}_{2}-0,011 \mathrm{x}_{3}+0,006 \mathrm{x}_{4}-0,017 \mathrm{x}_{5}
$$




\section{Faktor Harga}

a) Harga Tempe $\left(\mathrm{x}_{1}\right)$

Berdasarkan Tabel 4. Harga tempe ( $\left.\mathrm{x}_{1}\right)$ memiliki koefisien yang bernilai positif sebesar 1,011. Tanda positif ini menunjukan hubungan yang searah antara harga tempe dengan jumlah permintaan tempe untuk konsumsi. Hasil ini berarti bahwa jika ada kenaikan harga tempe sebesar 10 persen, maka akan terjadi peningkatan permintaan tempe sebesar 10,11 persen. Hal ini tidak sesuai dengan teori permintaan yang menyatakan bahwa, jika harga barang naik maka permintaan akan turun, tetapi hasil regresi tersebut sejalan dengan penelitian Lukman (2007), yang menyatakan bahwa meskipun harga tempe naik tidak akan mempengaruhi permintaan tempe. Hal ini dikarenakan tempe menyerupai makanan pokok karena bersumber dari kedelai dan di kalangan masyarakat diterima sebagai jenis pangan sehari-hari yang keberadaannya harus ada melengkapi nasi. Selain itu tempe merupakan jenis makanan yang permintaanya tidak terlalu responsif oleh faktor harga (inelastis). Nilai signifikansi variabel harga tempe di Kota Mataram berdasarkan hasil uji t yang dilakukan adalah 0,000 atau $<5$ persen yang artinya harga tempe berpengaruh nyata (signifikan) terhadap permintaan tempe di Kota Mataram. Hasil ini sejalan dengan penelitian Apridar (2008); Ulfa (2011); Hanafi et al., (2014); dan Prasetyo et al., (2019) yang menyatakan bahwa harga tempe berpengaruh nyata (signifikan) terhadap permintaan tempe.

b) Harga tahu $\left(\mathrm{x}_{2}\right)$

Berdasarkan Tabel 4, dapat diketahui bahwa koefisien regresi variabel harga tahu $\left(\mathrm{x}_{2}\right)$ bernilai positif sebesar 0,007 . Tanda positif ini menunjukan hubungan yang searah antara harga tahu dengan jumlah permintaan tempe. Dengan kata lain jika ada kenaikan harga tahu maka akan terjadi peningkatan permintaan tempe. Hal tersebut dikarenakan tahu merupakan barang substitusi. Hasil regresi tersebut sejalan dengan penelitian Ulfa (2011) yang menyatakan bahwa tahu merupakan barang substitusi (barang pengganti) dari tempe. Jika harga tahu naik maka orang akan beralih membeli tempe. Nilai signifikansi dari harga tempe di Kota Mataram berdasarkan hasil uji t yang dilakukan adalah 0,459 atau > 5 persen yang artinya harga tahu tidak berpengaruh nyata (tidak signifikan) terhadap permintaan tempe di Kota Mataram. Hasil ini sejalan dengan penelitian Hanafi et al., (2014) dan Prasetyo et al., (2019) yang menyatakan bahwa harga tahu tidak berpengaruh nyata (tidak signifikan) terhadap permintaan tempe.

c) Harga telur $\left(\mathrm{x}_{3}\right)$

Berdasarkan Tabel 4, dapat diketahui bahwa variabel harga telur $\left(\mathrm{x}_{3}\right)$ memiliki koefisien yang bernilai negatif sebesar 0,011 . Tanda negatif ini menunjukan hubungan yang berlawanan antara harga telur dengan permintaan tempe. Hal ini sejalan dengan penelitian Ulfa (2011) yang menyatakan bahwa jika harga telur naik maka seseorang akan membeli barang lain seperti daging ayam, daging sapi, atau lainnya dari pada membeli telur dan tempe. Pernyataan tersebut juga sejalan dengan penelitian Prasetyo et al., (2019), yang mengatakan seseorang akan membeli barang lain jika permintaan barang komplementer dari tempe menurun. Nilai signifikansi dari harga telur di Kota Mataram berdasarkan hasil uji t yang dilakukan adalah 0,353 atau > 5 persen yang artinya harga telur tidak berpengaruh nyata (tidak signifikan) terhadap permintaan tempe di Kota Mataram. Hasil ini sejalan dengan penelitian Hanafi et al., (2014), yang menyatakan bahwa harga telur tidak berpengaruh nyata (tidak signifikan) terhadap permintaan tempe. 


\section{Faktor Karakteristik Konsumen}

a) Jumlah anggota keluarga $\left(\mathrm{x}_{4}\right)$

Berdasarkan Tabel 4, dapat diketahui bahwa variabel jumlah anggota keluarga $\left(\mathrm{x}_{4}\right)$ memiliki koefisien regresi yang bernilai positif sebesar 0,006. Tanda positif ini menunjukan hubungan yang searah antara jumlah anggota keluarga dengan permintaan tempe. Artinya jika jumlah anggota keluarga bertambah 10 persen, maka akan ada peningkatan permintaan tempe sebesar 0,06 persen. Hal ini sejalan dengan penelitian Sarwono (2002), yang menyatakan bahwa semakin banyak jumlah anggota keluarga maka semakin meningkat juga jumlah permintaan tempe. Nilai signifikansi dari jumlah anggota keluarga di Kota Mataram berdasarkan hasil uji t yang dilakukan adalah 0,740 atau > 5 persen yang artinya jumlah anggota keluarga tidak berpengaruh nyata (tidak signifikan) terhadap permintaan tempe di Kota Mataram. Temuan ini menunjukkan bahwa banyaknya jumlah anggota keluarga tidak serta merta berpengaruh pada permintaan tempe, karena setiap orang memiliki preferensi dan selera yang berbeda dalam mengonsumsi berbagai jenis makanan. Hasil ini sejalan dengan penelitian Hanafi et al., (2014) yang menyatakan bahwa jumlah anggota keluarga tidak berpengaruh nyata (tidak signifikan) terhadap permintaan tempe.

b) Jumlah pendapatan keluarga $\left(\mathrm{x}_{5}\right)$

Berdasarkan Tabel 4, dapat diketahui bahwa variabel jumlah pendapatan keluarga $\left(\mathrm{x}_{5}\right)$ memiliki koefisien regresi yang bernilai negatif sebesar 0,017 . Tanda negatif ini menunjukkan pengaruh yang berlawanan antara pendapatan dengan permintaan tempe. Artinya jika jumlah pendapatan naik sebesar 10 persen, maka akan ada penurunan permintaan tempe sebesar 0,17 persen. Semakin tinggi pendapatan yang diperoleh masyarakat maka semakin turun permintaan tempe. Hal ini membuktikan juga bahwa pada kasus konsumen di kota mataram, tempe merupakan barang inferior, yaitu barang yang semakin berkurang apabila pendapatan masyarakat semakin meningkat/naik. Artinya konsumen akan mengalihkan sebagian pendapatannya untuk membeli jenis makanan lain yang menurut persepsi konsumen lebih baik atau memiliki variasi gizi dan protein yang lebih lengkap. Hasil regresi tersebut juga sejalan dengan penelitian Fatih (2003), yang menyatakan bahwa jika pendapatan masyarakat naik maka keinginan untuk membeli tempe akan berkurang. Tetapi tidak sejalan dengan penelitian Ulfa (2011), yang menyatakan bahwa apabila pendapatan seseorang naik maka permintaan tempe juga akan naik. Nilai signifikansi dari jumlah pendapatan keluarga di Kota Mataram berdasarkan hasil uji t yang dilakukan adalah 0,034 atau < 5 persen yang artinya jumlah pendapatan keluarga berpengaruh nyata (signifikan) terhadap permintaan tempe di Kota Mataram. Hasil ini sejalan dengan penelitian Hanafi et al., (2014), yang menyatakan bahwa jumlah pendapatan keluarga berpengaruh nyata (signifikan) terhadap permintaan tempe pada taraf signifikansi sebesar 0,15 .

\section{Uji Signifikansi Serentak (Uji-F)}

Berdasarkan Tabel 4 dapat diketahui bahwa nilai F hitung sebesar 1629,23 dengan probabilitas 0,000 yang lebih kecil dari taraf nyata 5 persen Maka Ho ditolak dan H1 diterima, yang artinya variabelvariabel bebas yang diamati dengan tingkat kepercayaan 95 persen yaitu harga tempe, harga tahu, harga telur, jumlah anggota keluarga dan jumlah pendapatan keluarga secara bersama-sama (serentak) memiliki pengaruh nyata (signifikan) terhadap permintaan tempe di Kota Mataram. 


\section{Uji Koefisien Determinasi (R Square)}

Berdasarkan Tabel 4 juga menyajikan nilai koefisien determinasi, dimana nilai tersebut menunjukkan seberapa besar variabel dependen dapat dijelaskan oleh variabel independen dalam model. Berdasarkan hasil dari analisis diperoleh nilai $\left(\mathrm{R}^{2}\right)$ sebesar 0,997. Hal ini menunjukkan bahwa 99,7 persen permintaan tempe di Kota Mataram dapat dijelaskan oleh variasi variabel bebas yang digunakan dalam model persamaan regresi linier berganda yaitu harga tempe, harga tahu, harga telur, jumlah anggota keluarga, dan jumlah pendapatan keluarga. Sedangkan sisanya sebesar 0,3 persen dijelaskan oleh variabel lain di luar model.

\section{PENUTUP}

\section{Simpulan}

(a) Karakteristik konsumen yang mengkonsumsi tempe di Kota Mataram berbeda-beda berdasarkan posisi dalam keluarga, jenis kelamin, umur, tingkat pendidikan, jenis pekerjaan, dan jumlah anggota keluarga. (b). Hasil analisis uji t didapat bahwa hanya variabel harga tempe dan jumlah pendapatan keluarga yang memiliki pengaruh (signifikan) secara parsial terhadap permintaan tempe di Kota Mataram pada tingkat kepercayaan 95 persen. Secara serentak variabel independen yang meliputi variabel harga tempe, harga tahu, harga telur, jumlah anggota keluarga, memiliki pengaruh terhadap permintaan tempe di Kota Mataram. Hasil pengujian Koefisien Determinasi didapat 99,7 persen, artinya permintaan tempe di Kota Mataram dapat dijelaskan oleh seluruh variabel dalam model yaitu harga tempe, harga tahu, harga telur, jumlah anggota keluarga, dan jumlah pendapatan keluarga. Sedangkan sisanya sebesar 0,3 persen dijelaskan oleh variabel lain di luar model.

\section{Saran}

Disarankan agar peneliti selanjutnya lebih memperhatikan analisis elastisitas dari setiap variabel independen agar dapat diketahui tingkat responsif permintaan tempe pada setiap perubahan dari faktorfaktor yang mempengaruhinya.

\section{DAFTAR PUSTAKA}

Apridar. (2008). Analisis Tentang Permintaan Tempe di Kota Lhokseumawe. Jurnal Manajemen, Akuntansi dan Bisnis. Vol 6 No.1

Astawan, M. (2003). Mari, Ramai-ramai Makan Tauge..!

http://www.kompas.com/kesehatan/news/0304/23/003738.htm. 20/01/2008.

Ashari, M. I. (2018). Optimalisasi Keuntungan Agroindustri Tahu dan Tempe di Kota Mataram. Jurnal Repository Universitas Mataram. http://eprints.unram.ac.id/5905/

Fatih, Alawi. (2003). Faktor-Faktor yang Berhubungan dengan Konsumsi Tempe pada Remaja di SMUN 1 Slawi dan SMUN 1 Tegal (skripsi).IPB. 2003.

Hanafi, F. I., Daris, E., \& Rochaeni, S. (2014). Analisis Faktor-Faktor yang Mempengaruhi Permintaan Tempe di Kelurahan Jurangmangu Timur, Pondok Aren, Tangerang Selatan. AGRIBUSINESS JOURNAL, 8(1), 45-58.

Lukman. (2007). Pengantar Teori Mikro Ekonomi. (Jakarta : UIN Jakarta Press, 2007).

Noertjahyo, J A. (2005) Dari Ladang Sampai Kabinet Menggugat Nasib Petani. (Jakarta: Penerbit Buku Kompas,). 
Nursan, M., \& Septiadi, D. (2020). Penentuan Prioritas Komoditas Unggulan Peternakan di Kabupaten Sumbawa Barat. JIA (Jurnal Ilmiah Agribisnis): Jurnal Agribisnis dan Ilmu Sosial Ekonomi Pertanian, $5(1), 29-34$.

Prasetyo, R. E., Sayekti, W. D., \& Kasymir, E. (2019). Tingkat Kepuasan dan Faktor-Faktor Yang Mempengaruhi Permintaan Tempe Oleh Konsumen Rumah Tangga Di Kota Bandar Lampung. Jurnal Ilmu-Ilmu Agribisnis, 6(4), 368-375.

Sarwono, B. (2002) Membuat tempe dan oncom. Jakarta: PT. Penebar Swadaya.

Septiadi, D., Harianto, H., \& Suharno, S. (2016). Dampak Kebijakan Harga Beras dan Luas Areal Irigasi Terhadap Pengentasan Kemiskinan di Indonesia. Jurnal Agribisnis Indonesia, 4(2), 91-106.

Septiadi, D., \& Joka, U. (2019). Analisis Respon dan Faktor-Faktor yang Mempengaruhi Permintaan Beras Indonesia. AGRIMOR, 4(3), 42-44.

Septiadi, D., Sari, N. M. W., \& Zainuddin, A. (2020). Analisis Permintaan Konsumsi Cabai Rawit pada Rumah Tangga di Kota Mataram. AGRIMOR, 5(2), 36-3.

Septiadi, D., Suparyana, P. K., \& FR, A. F. U. (2020). Analisis Pendapatan dan Pengaruh Penggunaan Input Produksi Pada Usahatani Kedelai di Kabupaten Lombok Tengah. JIA (Jurnal Ilmiah Agribisnis): Jurnal Agribisnis dan Ilmu Sosial Ekonomi Pertanian, 5(4), 141-149.

Suparyana, P. K., Sukanteri, N. P., \& Septiadi, D. (2020). Stategi Pengembangan Usaha Produksi Kue Pada Kelompok Wanita Tani Ayu Tangkas Di Kecamatan Selemadeg Timur, Bali. AGRISAINTIFIKA: Jurnal Ilmu-Ilmu Pertanian, 4(1), 46-59.

Triastono, J., Kurniyati, E., \& Jatuningtyas, R. K. (2020). Status dan Strategi Pengembangan Kedelai Untuk Swasembada di Indonesia. 215-226. Prosiding Seminar Nasional Pertanian Peternakan Terpadu Ke-3, Universitas Muhammadiyah Purworejo.

Ulfa, A. (2011). Analisis Faktor-faktor yang mempengaruhi permintaan tempe di Desa Jombang, Kecamatan Ciputat, Kota Tangerang Selatan, Provinsi Banten.

Winarsi, H., \& Purwanto, A. (2010). Efek Suplementasi Ekstrak Protein Kecambah Kedelai Terhadap Kadar Il-1beta Penderita Diabetes Tipe-2 [The Effect of Soy Germ Protein Extract Supplementation on the Level of IL-1 Beta of Type-2 Diabetic Woman]. Jurnal Teknologi dan Industri Pangan, 21(1), 6-6. 